\title{
Speech-activated myoclonus masquerading as stuttering
}

占

Figure Surface EMG during speech and during grimacing

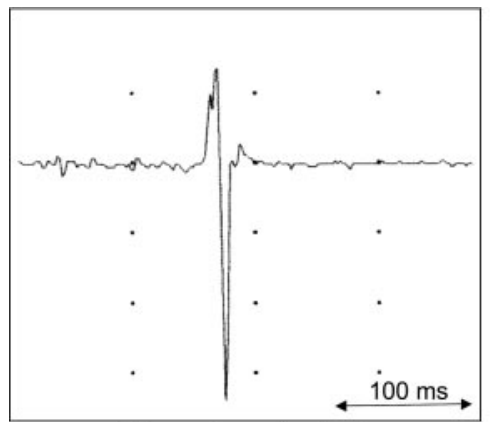

Speech-activated myoclonic contraction

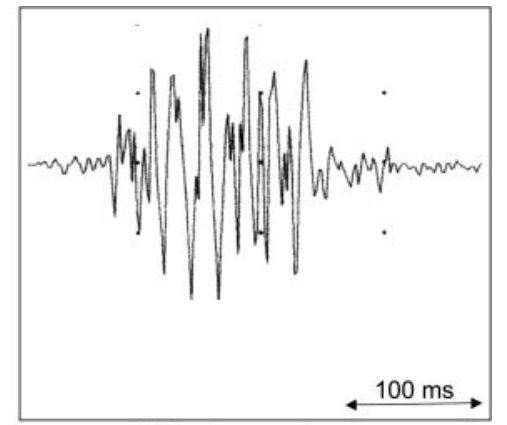

Voluntary grimace

Surface EMG of the sternocleidomastoid and pharyngeal muscles during speech revealed short-duration, high-amplitude bursts ( $<100 \mathrm{msec}$ ) suggestive of cortical myoclonus (A). This is in contrast to the relatively prolonged bursts ( $>250 \mathrm{msec})$ of voluntary muscle contraction, as demonstrated when the patient voluntarily grimaced as quickly as possible (B).

Despite having had normal speech until age 21 when he contracted varicella encephalitis, this 53 -year-old man had always considered himself a stutterer. Neurologic examination revealed lightning-like facial and neck contractions during speech, which were absent at rest (video). Brain and cervical spine MRI had normal results. Surface EMG confirmed intermittent high-amplitude, short-duration bursts suggestive of cortical myoclonus (figure and video).

Speech-activated myoclonus is an unusual variant of segmental action myoclonus. ${ }^{1,2}$ The etiology in this patient was likely postinfectious, and treatment with valproic acid led to a moderate symptomatic improvement. The myoclonus occurred with speech in both English and his native Ukrainian.

Jeffrey M. Gelfand, MD, Alexandra B. Nelson, $M D, P h D$, Robin D. Fross, MD, Graham A. Glass, $M D$, San Francisco (J.M.G., A.B.N., R.D.F., G.A.G.) and Hayward (R.D.F.), CA

Disclosure: Dr. Graham Alec Glass has received personal compensation for speaking and consulting on behalf of Allergan, Inc. UCSF Medical Center holds both an unrestricted educational grant and a research grant from Allergan, Inc.

Supplemental data at www.neurology.org
Address correspondence and reprint requests to Dr. Graham A. Glass, Department of Neurology, University of California, San Francisco, 4150 Clement Street 127P, San Francisco, CA 94121; graham.glass@ucsf.edu

1. Slee M, Parasivam S, Blessing B, Truck K, Day B, Thyagarajan D. Speech-activated myoclonus: an uncommon form of action myoclonus. Mov Disord 2005;20:1120-1126.

2. Bartolomei F, Farnarier G, Elias Z, et al. Facial reflex myoclonus induced by language: a neuropsychological and neurophysiological study. Neurophysiol Clin 1999;29:263-270. 


\section{Neurology}

Speech-activated myoclonus masquerading as stuttering

Jeffrey M. Gelfand, Alexandra B. Nelson, Robin D. Fross, et al.

Neurology 2009;72;1964

DOI 10.1212/WNL.0b013e3181a8cea6

This information is current as of June 1, 2009

\section{Updated Information \&}

Services

Supplementary Material

\section{References}

Subspecialty Collections

\section{Permissions \& Licensing}

Reprints including high resolution figures, can be found at: http://n.neurology.org/content/72/22/1964.full

Supplementary material can be found at: http://n.neurology.org/content/suppl/2009/05/29/72.22.1964.DC1

This article cites 2 articles, 0 of which you can access for free at: http://n.neurology.org/content/72/22/1964.full\#ref-list-1

This article, along with others on similar topics, appears in the following collection(s):

All Movement Disorders

http://n.neurology.org/cgi/collection/all_movement_disorders

Myoclonus

http://n.neurology.org/cgi/collection/myoclonus

Stuttering

http://n.neurology.org/cgi/collection/stuttering

Information about reproducing this article in parts (figures,tables) or in its entirety can be found online at:

http://www.neurology.org/about/about_the_journal\#permissions

Information about ordering reprints can be found online: http://n.neurology.org/subscribers/advertise

Neurology $®$ is the official journal of the American Academy of Neurology. Published continuously since 1951, it is now a weekly with 48 issues per year. Copyright . All rights reserved. Print ISSN: 0028-3878. Online ISSN: 1526-632X.

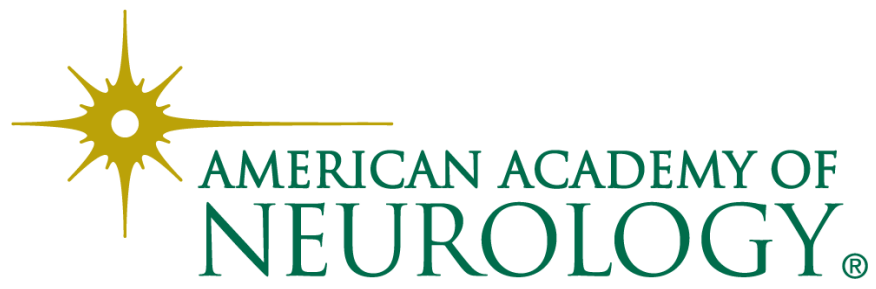

